\title{
MODERATION IN FALAK: Respond on the Variaty of Month Arrival Determination
}

\author{
Oleh : Rahmatiah HL \\ E-mail : rahmatiah.rahmatiah69@gmail.com \\ Fakultas Syariah dan Hukum UIN Alauddin Makassar
}

\begin{abstract}
This study aims to elaborate the maslahah mursalah theory in responding to differences in the determination of the beginning of the Hijri month in religious moderation and examining the idea of wujū al -hilāl, rukyat al-hilāl and Imkān al-Rukyat theory in the analysis of religious moderation. The research method employes comparative study. A comparative study is comparing one idea to another and the results of one research with other tasks. The results showed that hisab and rukyah combination is possible to practice in Indonesia to create benefits based on maslahah mursalah. The maslahah mursalah approach is used to formulate laws based on maslahat considerations, a priority in maqasid al-sharia. The use of maslahah mursalah can be agreed upon. Besides, the Indonesian Muslim Ummah should be together in the implementation of worship for the sake of achieving a strong Islamic ukhuwah. Religious moderation is crucial to bridge the differences in determining the beginning of the Hijri month. The Falak science experts in charge of this issue are responsible for formulating the criteria for determining the beginning of the Hijri month, mainly related to fasting. 01 Ramadan, Eid on 01 Shawwal and 10 Zulhijjah, which can be accepted by those who use the criteria of rukyat al-hiläl and wujüd al-hiläl. In this way, efforts towards the unification of the Hijriyah calendar can be realized.
\end{abstract}

Keywords : Falak; Maslahah Mursalah; Moderation

\section{INTRODUCTION}

In the last two years, the Ministry of Religion has again socialized religious moderation, namely understanding and practising spiritual teachings in a way that is not extreme, either the extreme right or the radical left. The emergence of hate speech and the emergence of a rift between religious communities is a problem our nation faces. Moderation's momentum is considered urgent to stabilize the ummah's spiritual understanding in Indonesia's Republic (NKRI).

Various tribes, languages, cultures created humans and even religions to know each other, cooperate and respect each other. QS al-Hujurat: 13 Allah says :

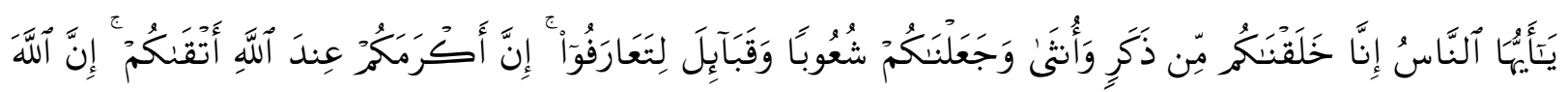




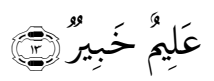

Translation:

O humanity! Indeed, we created you from a male and a female, and made you into peoples and tribes so that your may 'get to' know one another. Surely the most noble of you in the sight of Allah is the most righteous among you. Allah is truly AllKnowing, All-Aware

Allah SWT created the richness and beauty of the nation and the landless water, and the variety that should be the grace and door unification nation not with symbols specific. Thus, only in the determination of aw al Ramadhan and Syawal, the Ministry of Religion of the Republic of Indonesia has acted as a mediator every year when announcing and determining Ramadan fasts and holidays.

\section{Arrival of Ramadan Determination}

The Arrival of the Hijri month should be determined by the Ministry of Religion, which can prevent differences in determining fasting and holidays. The Ministry of Religion of the Republic of Indonesia's existence and development are very strategic and capable of realizing the unification of the Hijriyah gender. Moderate does not make someone weak in religion, does not have militancy, is not severe, and does not practice their religion. On the contrary, being moderate in faith is a middle way in religious diversity and is a cultural heritage of the archipelago. Likewise, in determining the beginning of the month of Ramadan, which focuses on the visibility of the hilal, differences often occur. With differences in practising Islamic teachings, they have appeared in celebrating Eid al-Fitr and Eid al-Adha.

The initial determination of Ramadan and Syawal should not have shown an extreme attitude towards certain ideologies. On the contrary, civil society such as Islamic community organizations (mass organizations) such as Nahdlatul Ulama (NU) and Muhammadiyah should not impact differences in the determination of the beginning of the month, which has occurred several years ago.

The study of religious moderation is fascinating to discuss in religious studies, specifically in this writing. Religious moderation is associated with the determination of the beginning of the month of Ramadan and Syawal because the theory used to determine the beginning of the month is different and the results obtained are different so that there is a difference in determining the start of the month, mainly related to the month. Ramadan, Shawwal and Zulhijjah. It's just that there is only one object in the determination of the beginning of Ramadan and the front of Syawal, namely HILĀL.

Hilal is the moon's appearance as seen from the earth after ijtima' or conjunction. The difference between place and time on earth affects Hiläl. It appears very dim compared to sunlight or mega dusk because it is light obtained from sunlight reflection. Thus Hiläl can only be observed shortly after sunset.

The determination of the beginning of the month is very significant for the months in the hijrah calendar concerning the implementation of worship. Some Muslims argue 
to determine the beginning of the month of qamariyah. It is necessary to observe hiläl directly. Some others argue that it is enough to determine the beginning of the month by doing reckoning (mathematical/astronomical calculations) without following the hiläl. Both claim to have a factual basis.

In Indonesia's case, the theoretical approach was pioneered by Muhammadiyah by carrying out the theory of wuju al-hilal to determine the beginning of the month of qamariyah. In contrast, the empirical approach was used by Nahdlatul Ulama (NU) by making the visibility of the hiläl as a guide in making observations. For NU, as stated by Ghazali Masruri, hilāl must be visible and apparent. ${ }^{1}$ This difference in approach is one source of problems in determining the Hijri month's start in Indonesia.

\section{METHOD}

The research method used is a comparative study research. Comparative study is comparing one theory to another theory, and the results of one study with other studies. In addition, this research is a type of qualitative research with library research studies. Qualitative research is research that uses a natural setting, with the intention of interpreting the phenomena that occur and is carried out by involving various existing methods. In this study, the author emphasizes his study of the differences in the determination of the beginning of the hijri month in relation to various modes of variation and the comparison to the theory of wujū al-hilāl, rukyat al-hilāl and Imkān al-Rukyat theory in the analysis of religious moderation. The research method used is a comparative study research. Comparative study is comparing one theory to another theory, and the results of one study with other studies. In addition, this research is a type of qualitative research with library research studies. Qualitative research is research that uses a natural setting, with the intention of interpreting the phenomena that occur and is carried out by involving various existing methods. In this study, the author emphasizes his study of the differences in the determination of the beginning of the hijri month in relation to various modes of variation and the comparison to the theory of wujū al-hilāl, rukyat al-hilāl and Imkān al-Rukyat theory in the analysis of religious moderation.

\section{RESULT \& DISCUSSION}

\section{A. Brief Meaning of Maslahah mursalah}

Etymologically, Maslahah mursalah consists of two words, namely maslahah and mursalah². In terminology, Imam al-Gazali in defining maslahah mursalah with Maslahat, which there is no evidence from syara' in the form of a particular text which cancels it and no one pays attention to it.

\footnotetext{
${ }^{1}$ For more reading, read "Hilal Redefinition of Uncertainty", published in the Monthly Islamic Magazine of the Khalifah', edition 3 Year I / 17 August-September 2008/14 Syakban-Ramadhan 1429, p. 7.

2 Some scholars call maslahah mursalah with the terms al-Munāsib al-Mursāl (popularized by Ibn Hājib and Baidhāwi), al-Istidlāl al-Mursāl (popularized by ash-Syātibi) and al-Ishtislāh (popularized by alGhazāli). See Rahmat Syafe'i, Ushul Fiqih Science (Cet.III; Bandung: Pustaka Setia, 2007), p. 118.
} 
Maslahah mursalah is part of the sources and methods in Islamic law that require special attention ${ }^{3}$. Although maslahah mursalah is not mentioned in the text textually, humans are substantially needed, especially those in direct contact with the Muslim's basic needs. Zaky al-Din Sya'ban stated that maslahah mursalah is one of the bases for making urgent religious regulations and makes it possible to produce good values if jurists can take a sharp look at what intersects with Islamic spiritual teachings ${ }^{4}$. Maslahah mursalah can be used as a method of ijtihad in solving contemporary legal problems that are not included in the text of the Qur'an and the sunna. Therefore, observers of Islamic law must understand the legal issues in society more deeply and resolve them.

\section{B. Relation of Determination of the Arrival of the Month of the Hijri Year and Religious Moderation with the Maslahah mursalah Approach}

The benefit of something is necessary for human life, more specifically for Muslims. Legal issues where there is no indication of syarak, both from the Koran and the sunna as the primary source in Islamic law, can be resolved by the ijtihad method, which uses ratio. Reasoning can solve legal problems by referring to benefits that are not mentioned in the syarak but do not come out and violate the rules of the syarak. Such services are known in the vocabulary of Usul Fiqh with maslahah mursalah. The maslahat becomes something good according to reason, considering that it can manifest goodness or avoid badness for the people.

The problem in Islamic law that often causes polemics is the determination of the Hijri month's beginning, especially one Ramadan, one Shawwal and 10 Zulhijjah. Muslims in parts of the world frequently experience differences in carrying out the beginning of the fast of Ramadan and two eid give diversity of conditions of Muslims today ${ }^{5}$. The difference in implementation is understandable because the understanding and methods used are different. Through the Ministry of Religion, the government established the Hisab and Rukyah Agency, which aims to unite Muslims.

The effort to combine hisab and rukyah is possible to practice in Indonesia to create benefits based on maslahah mursalah. The maslahah mursalah approach is used to formulate laws based on maslahat considerations, a priority in maqasid al-sharia. In fact, the use of maslahah mursalah can be agreed upon.

The distance between countries influences the view of Al-Syafii jurisprudence on determining fasting month. The argument is based on Kuraib hadith. Therefore, seeing the hilal (rukyah) as a sign of the end of the month of the Hijri year in a country can be analogous to seeing the sun and dawn, which can affect the difference in prayer times in different countries. The difference in the sunrise in certain countries and other

\footnotetext{
${ }_{3}^{3}$ Abu Hamid al-Gazali, al-Mustasyfa fi 'Ilm al-Usul (Bairut; Dār al-Kutūb al-Ilmiyyah,1993), p. 311.

${ }^{4}$ Faisal Yahya Yacob and Faisal Ahmad Syah, " Metode Penentuan Awal Ramadhan dan Hari Raya " in Futura Islamic Journal, Vol. 16, No. 1, 2016, p. 9.

${ }^{5}$ Faisal Yahya Yacob dan Faisal Ahmad Syah, "Metode Penentuan Awal Ramadhan dan Hari Raya" dalam Jurnal Islam Futura, Vol. 16, No. 1, 2016, h. 9.
} 
countries affects the difference in prayer times caused by the difference in sunrise and sunset and dawn. The difference in the new moon's appearance according to its position in each country can affect the beginning and end of the Hijri year's month. Thus, each country, more specifically Indonesia, through the Ministry of Religion, has the authority to determine the beginning and end of the month of Ramadan according to the position of the hilal (mathla' al-hilal). It is not obliged to follow other countries' decisions as long as these countries have a hilal place, which is different.

The obligation to perform fasting in the month of Ramadan is based on the circulation of Falak. Still, the impact of that circulation results in a time difference from one country to another. Therefore, it is very appropriate to determine the beginning of fasting to follow each country's differences.

The Ministry of Religion establishes a method for determining the hilal with ru'yah al-hilal with the criteria of imkan al-ru'yah. The hadith that tells about the rukyah can be understood both textually and contextually. Textual understanding gives birth to the idea of seeing the hilal directly, either with the eye or with the aid of binoculars. Yusuf al-Qaradawi that as a way or means of determining the appearance of the new moon, must be used based on a higher class ( qiyas awlawi) because the reckoning model is mostly developed today by scholars who emphasize accuracy.

Another consideration is the merger of rukyah and hisab, especially in Indonesia, by the Ministry of Religion by looking at the side of religious moderation, which is much more urgent. The phenomenon of the beginning of fasting in Ramadan and having a day is often different. Thus, making the proposition of maslahah mursalah as reinforcement in responding to differences in implementing the beginning of the month of the Hijri year is a moderate form of religion. Stability is much more essential to carry out than to see the debate over the correct method between hisab and rukyah. The rule of giving priority to more urgent benefits If several maslahat are conflicting, the higher the maslahat is prioritized, and if there are several mafsadat colliding with each other, the lighter one contains the mafsadat.

This rule implies that several benefits cannot be worked out and combined at once when coupled with it. The priority scale in such a situation is to prioritize the benefits of higher benefits. The higher Maslahat contains goodness and is more loved by Shari. However, if several of these benefits can be combined, it becomes more critical.

Contextualization of religious moderation is a moderate behaviour between the options that exist so that the attitude of religious moderation is the key to producing harmony and tolerance in the practice of Islamic teachings, including in the context of combining hisab and rukyah. Therefore, combining hisab and rukyah follows the essence of maslahah mursalah because the Shari'a provisions are usuli and furui not contradictory to the text. Combining the two methods has a more excellent benefit value, especially by relating to diversity and diversity in implementing religious moderation. 


\section{Wujū al-hilāl, rukyat al-hilāl and Imkān al-Rukyat theory in the analysis of religious moderation}

Muslims should be together in the implementation of worship for the sake of achieving a robust Islamic brotherhood. The astronomers in charge of this issue feel responsible for formulating criteria for determining the start of the month that can be accepted by all parties so that the idea of unification of the Hijriyah calendar can be realized immediately. The formulation of the Hijriyah calendar's consolidation must begin with the principles that underlie the Hijriyah calendar's formation, namely the beginning of the Hijri month. In this context, the determination of the beginning of the Hijri month cannot be separated from the criteria and methodology that are used as the basis for determining the beginning of the month. The varied standards and methods made it difficult to unify the Hijri calendar.

This reality is what happened in Indonesia. NU uses rukyat al-hiläl as a benchmark for entry at the beginning of the month, ${ }^{6}$ while Muhammadiyah uses the hisāb wujūd alhilāl method ${ }^{7}$ While the government adheres to imkān al-rukyat, if the three schools cannot be united in a single criterion mutually agreed upon, then the Hijri calendar's unification will only become a utopia. Apart from the requirements and methodology aspects, the different determination of the beginning of the Hijri month between NU, Muhammadiyah and the government is rooted in the difference between the results of rukyat in the field and hisäb. So far, the practice of rukyat has been equipped with telescope technology which can enlarge the image of the hilall. However, the telescope's capabilities are still limited by weather factors such as the sky's brightness. If the sky is cloudy, the hiläl will likely be difficult to rukyat even though the hilal is already above the horizon with an altitude above $2^{\circ}$. This is what needs to be studied in depth. As previously stated, one of the reasons for the difference in determining the start of the Hijri month lies in the difference in defining hiläl, both empirically and sociopsychologically. Sec fig empirical Muslims today have "divorced" the mathematical model of the motion and position of the moon (reckoning ) with observation data that can be trusted and is repeated at a later origin of its conditions are met (rukyat).

Rukyat al-hiläl is a method of determining the beginning of the qamariyah month employing rukyah, aka looking directly at the new moon or, more scientifically, called direct observation. Seeing the beginning of the month appearing has been done by Muslims who are guided by the hadith of the prophet Muhammad PBUH., Meaning: Naratted to us,' Abdullah bin Maslamah has told us, Malik, from Nafi 'from' Abdullah bin 'Umar radliallahu' anhu that the Messenger of Allah -peace and prayer of Allah be upon him- told about the month of Ramadan. Then he said: "Do not fast until you see

${ }^{6}$ PBNU Decree No. 311 / A.11.03 / 1/1994 regarding the Operational Guidelines for the Implementation of Ru' yah bil Fi'i in the NU Environment, article 1 sections a and $b$

7 Majelis Tarjih PP Muhammadiyah, "Penggunaan Ḥisāb dalam Penetapan Bulan Baru Hijriyah/ Qamariyah ". Paper presented at the Hisāb and Rukyat National Seminar in Jakarta on 20-22 May 2003, in Choirul Fuad Yusuf and Bashori A. Hakim (ed.), Hisāb Rukyat dan Perbedaannya (Jakarta: Proyek Peningkatan Pengkajian Kerukunan Hidup Umat Beragama Puslitbang Kehidupan Beragama Badan Litbang Agama dan Diklat Keagamaan Departemen Agama RI, 2004), p. 24. 
the new moon and do not. you break quickly until you see it. If a cloud hinders you, then estimate the number (number of days perfected ) ". (H R. al-Bukhariy-1773)

The method of determining the beginning of the month of Qamariyah in the Nahdlatul Ulama (NU) mass organization recognizes the limit of the hiläl, which is a defined limit that is likely to see the hilal which is $2^{\circ} 8$, this condition is the benchmark for measuring the size of the hilal. If anyone witnessed the beginning of the month or hiläl, brought $2^{\circ}$, the testimony is rejected. On the other side of the organization, Muhammadiyah use a method of reckoning manifestation of Al-Hilal are not using limit the appearance of the new moon, which is already w equivalent, then the next day is already beginning.

Wujūd al-hiläl is a criterion for determining the beginning of the month using two principles, namely: ijtima (conjuction) has occurred before sunset, and the moon sets after sunset, so that evening is called the beginning of the month, regardless of the altitude limit of the hiläl. The criteria for wujüd al-hiläl ${ }^{9}$ are determined based on:

1. There has been an ijtima ( conjuction);

2. The ijtima event occurred before sunset (ghurūb);

3. At the time of the setting sun, the disk of the moon is above the horizon.

The use of $h\}$ is $a>b$ for Muhammadiyah is considered more practical because it can determine the future with certainty so that preparations are more carefully planned. Besides, $h\}$ is $a>b$ also serves as a reflection of Muhammadiyah's belief in science. The results of $h\}$ isa $>b$ can be verified at any time and by anyone like this is not contained in rukyat ${ }^{10}$.

Rukyat al-hilāl, wujūd al-hilāl and imkān al-rukyat are a series of methods used the beginning of the month of Ramadan, Shawwal and zulhijjah. The methods try to unite between the imkān al-rukyat method, which tries to bridge the two forms of determining the month's start from NU and Muhammadiyah mass organizations. This has not been realized so far because the two mass organizations have maintained their methods so that reality appears, 2 (two) times Eid or fasting the next day.

Imkan ar-rukyat is a method used by the government to bridge the $h\}$ isa $>b$ method with the ru'yah method. This criterion applies wilayatul hukmi and becomes the basis for compiling the calendar of the Ministry of Religion of the Republic of Indonesia and standard taqwim as well as filtering reports on rukyatul hilāl. Local or regional Rukyat a determination method based on sightings particular region. Indonesia has done this, Brunei, Malaysia, and Singapore have agreed that wherever hilāl appear in the region will be decision-making basis, and consequently report rukyat al-hilal from the other areas will not be used as a basis in decision -making. ${ }^{11}$

8 PB NU, Pedoman Hisab dan Rukyat," (Jakarta, Lajnah Falakiyah PB NU, 1994), p. 2

${ }^{9}$ Majelis Tarjih dan Tajdid PP Muhammadiyah, Pedoman Hisab Muhammadiyah (Cet. II; Yogyakarta: MTT PP Muhammadiyah, 2009), p. 23 and h. 78.

10 Oman Fathurrohman, " Penentuan Awal Bulan Qamariyah Menurut Muhammadiyah ", Paper presented at the National Seminar on Determining the Beginning of the Month Qamariyah in Indonesia.

${ }_{11}$ Merajut Ukhuwah di Tengah Perbedaan, organized by the Majelis Tarjih dan Tajdid PP Muhammadiyah, Yogyakarta 27-30 November 2008, p. 13 
The role of religious moderation is needed to anticipate repeated mistakes, namely anticipating the emergence of the extreme right and extreme left. In this case, avoiding Muslims in one particular decision, because usually, congregations in specific community organizations are very panicky in their organizations' leaders' findings, so Eid often occurs. earlier than other conferences, namely the An-Nadzir congregation and the Naqsabandiyah congregation ${ }^{12}$, which they carry out the beginning of the fast in the month of Ramadan earlier than others, as well as problems with rukyat alhilāl, wujüd al-hiläl and imkān al-rukyat when at the same time some are already Eid but some are still fasting. In case Allah said in QS Yunus: 5 as follows:

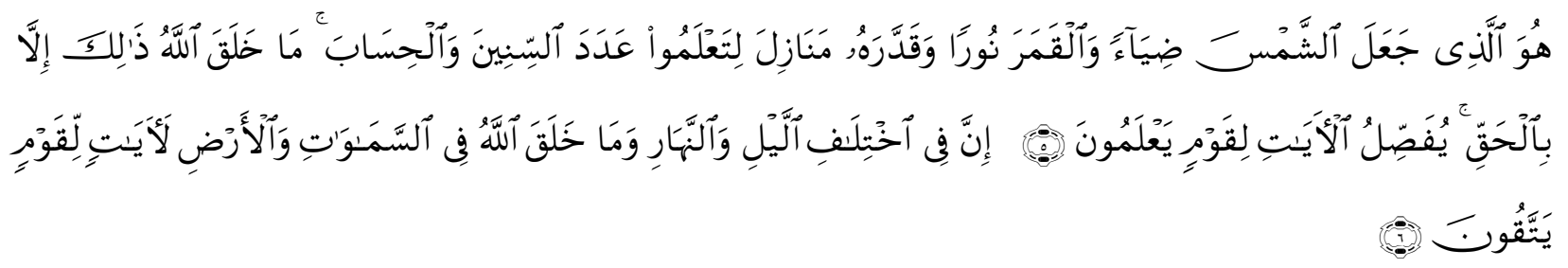

Translation:

He is the One Who made the sun a radiant source and the moon a reflected light, with precisely ordained phases, so that you may know the number of years and calculation 'of time'. Allah did not create all this except for a purpose. He makes the signs clear for people of knowledge.

The similarity of perception has been made to bridge the two, and even efforts have been made through organized international organizations in membership MABIMS (Malaysia, Brunei Darussalam, Indonesia, Singapore), with an agreement that specifically for the Indonesian region, the minimum altitude of the hilāl above the horizon of the mar'i is $2^{\circ} 13$.

Indonesian Muslim Ummah should be together in implementation worship for the sake of achieving a strong Islamic ukhuwah. Religious moderation is crucial to bridge the differences in the initial determination of Hijriyah. Falak science experts are in charge of formulating the criteria for determining the start of the month Hijriyah is mainly related to fasting 01 Ramadan, Eid on 01 Shawwal and 10th of Zulhijjah, which are acceptable to those who are using the criteria of rukyat al-hiläl and wujūd al-hiläl. Thus effort towards the unification of the Hijriyah calendar can be realized soon.

\section{Hijriyah Calendar, Symbol of Moderation in Religion}

Calendar or so-called almanack or calendar has become an essential part of people's daily lives. You can imagine without a calendar. We will be confusion to manage activities, determine appointments meetings, create work programs for an organization,

12 T. Djamaluddin, Renungan Tahun Bari 1419 H, Pelajaran Tiga Hari Raya, published in the people's minds, April 15, 1998.

13 Slamet Hambali, Almanak Sepanjang Masa (Semarang: IAIN Walisongo Postgraduate Program Semarang), p. 13 
even political and state activities. At first, people's life was elementary. The development of community life is increasingly becoming more complex. It is necessary to have a definite calendar system to regulate the activities to be carried out.

Several worships in Islam is associated with a specified time. That is why the Islamic calendar is so important because it is directly related to worship. Some prayers in Islam that use an explicit time standard are prayer, fasting, and Eid al-Fitr or Eid alAdha. There are no significant obstacles for prayer times because it is carried out on a monthly lunar calendar. Except for the Eid al-Fitr and Eid al-Adha prayers, which are stipulated concerning the determination of the months of Shawwal and Zulhijah ${ }^{14}$.

Differences in the implementation of fasting that often occur, especially in Indonesia, are due to differences in the use of methods and criteria in determining the start of the month of kamariyah. Among the astronomers and astronomers, someplace rukyat as part of the implementation of fasting. Others make Hisāb, with hilāl as the celestial body's object to determine the beginning of the Hijri month. But in reality, the Islamic calendar still varies, resulting in differences in determining the start of Ramadan and Syawal. Concrete evidence of the differences between Eid al-Fitr $1432 \mathrm{H}$ and the beginning of Ramadan $1433 \mathrm{H}$, which until now still leaves problems ${ }^{15}$. Likewise, the implementation is local, so there are often differences in determining Eid al-Adha between Saudi Arabia and other Islamic countries, such as the case of Eid al-Adha.

Adha $1431 \mathrm{H}$ ago between Indonesia and Saudi Arabia ${ }^{16}$. And theoretically, the differences will repeat themselves at the beginning of Ramadan 1434H / 2013M, the beginning of Ramadan 1435H / 2014M, and Idul Adha 1435H / 2014 M.17. Therefore, the presence of an integrated Islamic calendar is highly anticipated.

Hiläl is one of the astronomical phenomena that are very important in the Hijri calendar system. This is supported by Qs al-Baqarah / 2: 189.

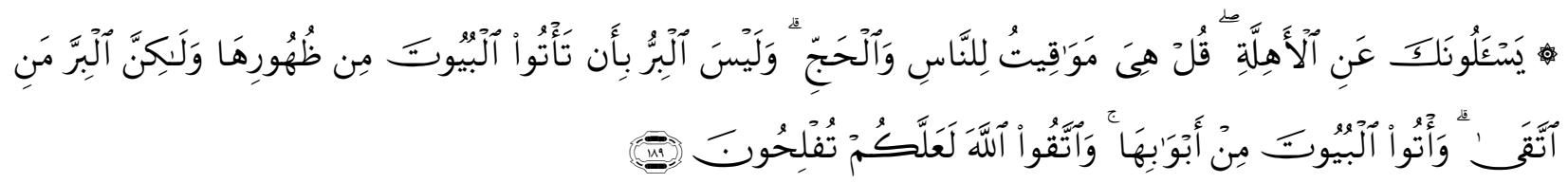

Meaning:

14 Agus Mustofa, Jangan Asal Ikut-ikutan Hisāb E Rukyat (Surabaya: PADMA Press), p.

86-87.

15 The difference between Eid al-Fitr $1432 \mathrm{H}$ is different from the previous events. The last year, it was calmer and more polite, but this year's Eid difference seemed less elegant and less wise. Moreover, in a trial, isbat tends to be a forum for judgment and truth claims . Read Media Indonesia, Friday, September 2, 2011, p. 1 and Media Indonesia, Saturday, September 3, 2011, p. 17. Also, read Agus Purwanto, "Sidang Itsbat sudah Tidak Relevan ", published in Suara Muhammadiyah magazine, No. 19 / Th. 96th, October 115,2011 , p. $28-30$

16 Government Decides on Eid Al-Adha November 17, published in Koran Tempo, Tuesday, November 9 , 2010, p. A7.

17 T. Djamaluddin, Astronomi Memberi Solusi Penyatuan (Jakarta: LAPAN; 2011), p. 30. 
They ask you 'O Prophet' about the phases of the moon. Say, "They are a means for people to determine time and pilgrimage." Righteousness is not in entering your houses from the back doors. Rather, righteousness is to be mindful 'of Allah'. So, enter your homes through their 'proper' doors, and be mindful of Allah so you may be successful.

Studies on the Hijri calendar will not be separated from discussing the basic concept of the hiläl. The basic idea of hiläl occupies a very strategic position in the Hijri calendar system. This is because determining the beginning of a new month's entry (new month) in the Hijri calendar system depends on this hiläl. Even studies in Hisāb science attempt to determine the position of the hiläl at the end of the Hijri month to determine the start of a new Hijri month. The minimum height of the hilāl, Falak scholars and astronomers, have different opinions about the provisions of the minimum size of the hiläl so that it can be seen, as follows:

1. Especially for Indonesia and MABIMS (Malaysia, Brunei Darussalam, Indonesia, Singapore), the minimum altitude of the hilāldi above the horizon of Mar' $i$ is $2{ }^{\circ}$.

2. According to Danjon (based on scientific studies by astronomers i), the criterion is that the moon's arc distance and the sun at sunset is a minimum of 70 .

3. Hilāl is likely to be seen with the naked eye with a 50:50 probability compiled by the Istanbul agreement at the Almanac Conference Islam in $1978 \mathrm{AD}$, i.e. minimum arc distance of $8.0^{\circ}$, minimum hiläl height of $5.0^{\circ}$.

4. According to Ilyas, the criterion is that the arc distance is at least 10.5 degrees, the hilal height is 5.0018 . Efforts to unify the Hijri calendar in several countries

The majority of the population is Muslim. In Indonesia, this initiative has been carried out several times, starting with the government's initiation, Islamic organizations, and academics.

The Indonesian government, which is entrusted with being the liaison in the religious commission between countries, cannot be separated from diplomacy's power. Not only as of the initiator of the establishment of international forums, but it also hosts several events. It started from the 1955 Asia-Africa Conference in Bandung, the 1976 ASEAN Summit in Bali, and 2012. Islamic Conference Organization States Parliament Conference in Palembang and the most supportive is the activity towards the unification of Islamic gender, namely the MABIMS Rukyat and Taqwim Islamic Council Conference in Denpasar Bali in 2012, and the 2014 MABIMS Muzakarah Rukyat and Islamic State Taqwim in Jakarta. In fact, in 2016, the International Hijri Calendar Unity congress was held.

Ukhuwah Islamiyah from various countries contributed significantly to the formation of Islamic gender unity so that the differences in the determination of the beginning of the month for those who use the theory of wuju al-hiläl, rukyat al-hiläl and the view of Imkann al-Rukyat can be minimized and do not occur in cults of one approach and their congregation, which in turn leads to differences in the implementation of their

18 Chairul Zen S., Ensiklopedia Ilmu Falak dan Rumus-rumus Hisāb Ilmu Falak, in http:// sumut.kemenag.go.id/file/file/RUKYAT/rimd1338174830.pdf accessed January 23, 2017 
primary worship. And Eid. Religious moderation is beneficial and can be used as an analysis tool for business unification of Islamic gender in Indonesia and Muslimmajority ASEAN countries.

\section{CONCLUSION}

Efforts to combine hisab and rukyah are possible to be practised in Indonesia to create benefits based on maslahah mursalah. Rukyat al-hilāl, wujūd al-hilāl and imkān alrukyat are a series of methods used during the beginning of the month of Ramadan, Shawwal and zulhijjah and the role of observers of hisab and rukyat is significant considering moderation in religion. Religious moderation is beneficial and can be used to analyze efforts to unite Islamic gender.

\section{IMPLICATIONS}

The unification of the Hijri calendar is the dream of many people. Muslims in Indonesia, especially in carrying out worship, related to the determination of 1 Ramadan, 1 Syawal, and 1 Dzulhijjah, and efforts to implement Muzakarah from the Ministry of Religion, should be done at the end of the year of the Islamic month. Rukyat al-hiläl, wujūd al-hiläl and imkān al-rukyat and religious moderation need to go hand in hand.

\section{BIBLIOGRAPHY}

Al-Quran and Translation

Agus, Purwanto. Sidang Isbat Sudah Tidak Relevan. Majalah Suara Muhammadiyah, No.19/Th. Ke-96, 2011.

Djamaluddin T. Renungan Tahun Baru 1419 H, Pelajaran Hari Raya, Jakarta 1998.

Djamaluddin T. Astronomi Memberi Solusi Penyatuan Ummat. Jakarta; Lapan, 2011.Faturrohman, Oman. Penentuan Awal Bulan Qamariyah Menurut

Muhammadiyah. Majelis Tarjih dan Tajdid PP Muhammadiyah: Yogyakarta, 2008.

Hambali, Slamet. Almanak Sepanjang Masa. Semarang; Program Pascasarjana IAIN Walisongo.

Hakim, A. Bashori dan Yusuf Fuad Choirul. Hisab Rukyat dan Perbedaannya.

Departemen Agama RI: Jakarta, 2004.

Majalah Islami Bulanan Khalifah, Redefinisi Hilal Sebuah Keniscayaan. Edisi III Tahun I/17 Agustus - September 2008/ 14 Syakban Ramadhan 1429.

Khalaf Syarifuddin, Amir. Masadir al-Tasyri al-Islami Fi ma La Nassa Fih, Cet.III Kuwait: Dar al Qalam, 1972.

Majelis Tarjih dan Tajdid PP Muhammadiyah, Pedoman Hisab Muhammadiyah.Cet. II; Yogyakarta; MTT PP Muhammadiyah, 2009

Mustofa, Agus. Jangan Asal Ikut-ikutan Hisab dan Rukyat. Surabaya: PADMA Press. 
. Koran Tempo, Pemerintah Putuskan Idul Adha, published on 17 November, 2010.

PBNU No.311/A.11.03/1/1994. Pasal 1 a \& b, Pedoman Operasional Penyelenggaraan Ru'yat bil Fi'li.

PBNU, Pedoman Hisab dan Rukyat. Jakarta: Lajnah Falakiyah, 1994.

S. Zen, Chairul. Ensiklopedia Ilmu Falak dan Rumusan-Rumus Hisab Ilmu Falak. Syafe"i, Rahmat. Ilmu Ushul Fiqhi, Cet.III, Bandung :Pustaka Setia, 2007.

Syarifuddin, Amir. Ushul Fiqih Jilid II, Cet.I ; Jakarta: Logos Wacana Ilmu, 1999. Syaban, al-Din Zaky. Usul al Fiqh al-Islami (al-Qahirah; Matbah Dar al-Ta"lif)

Syah, Ahmad Faisal dan Yacob, Yahya Faisla, Jurnal Islam Futura, Metode Penentuan Awal Ramadhan dan Hari Raya, Vol.16, No.1 Tahun 2016.

S. Zen Chairul. Ensiklopedi Ilmu Falak dan Rumus-Rumus Hisab Ilmu Falak. On http;sumut.kemenag.go.id/file/file/Rukyat/rimdl338174830 